\section{But who is the enemy?}

\section{Washington}

LAST year's renaming of the National Bureau of Standards as the National Institutes of Science and Technology (NIST) was intended as more than a cosmetic change. In its capacity as a producer of innovative, state-of-the-art devices for fundamental scientific measurement and calibration, NIST was deemed particularly suitable as a federal agency that could lead the way in turning technological research into commercial products. Thus the Advanced Technology Program (ATP) was begun earlier this year, to support joint ventures by NIST and industrial partners. But in considering continued authorization of funds for NIST, Congress has run up against the legislative puzzle of how to construct ATP so that foreign companies do not use it to gain access to US technology, trying at the same time not to hedge the programme about with so many rules and restrictions that it defeats the US companies who are meant to benefit from it.

What makes such problems additionally difficult in the United States is the general political belief that the government should not directly tell industry what to do, or hand out money to develop specific commercial products. As Representative Don Ritter (Republican-Pennsylvania) put it last week at a hearing on "What is a US company?", it has become an "article of faith" that market forces should determine the direction that industry chooses to move in. Consequently, the US government, unlike its Japanese or European counterparts, can give direction to industry only by enacting legislation that encourages some activities and discourages others.

At last week's hearing, before House of Representatives subcommittees on science, research and technology and on international scientific cooperation, the 'Japanese' point of view was put by John Kline of Georgetown University, who argued that the key to success in joint ventures was for the government side to decide clearly what the aim of a project was, and to assemble the components to achieve it. "Foreignness", Kline said, is intrinsically neither good nor bad; what mattered was whether a given company had expertise necessary for the success of the project in question. The way to do joint ventures, he suggested, was not to set general rules but to examine each case separately.

But this is an approach neither the Congress nor the administration is yet prepared to accept. Robert Cohen, an economic consultant, and Larry Hecht, of Lehigh University, both argued for a strategy along the lines of the act that set up ATP, in which rules are given for deciding whether a company is American or foreign, and specific conditions are applied to the participation in a joint venture of a company deemed to be foreign. But, as Kline remarked, the ATP rules in their present form can exclude a foreign company from partnership for reasons that have nothing to do with the company itself, for example because of restrictive trade practices by the foreign government.

Foreignness under the ATP rules is determined simply according the nationality of the majority of shareholders. Hecht acknowledged that this was a coarse distinction, but argued that it was the most useful definition available. The United States is the "least restrictive" of 35 countries in which he had done business, he said, but could no longer afford to be magnanimous in its treatment of foreign competitors. Hecht suggested that foreign companies should be excluded outright from any ventures in "sensitive" areas, where sensitivity is determined according to the economic as well as the military importance of a technology, and further proposed that US companies operating in such areas might be given effective legal protection from foreign takeovers.

Such stern measures were opposed by Mark Rochkind, president of the North American operation of the Dutch electronics company Philips and Neil Vander Dussen, president of the Sony Corporation of America, who pointed out that their companies, although foreign according to the ATP definition, were in effect domestic. They contributed to the US economy, carried out research in the United States, and even exported manufactured products back to their home countries. Equally, some US companies were moving their manufacturing operations into countries with lower labour rates, such as Mexico and Korea; these companies offer a route by which the results of federally-funded research can go abroad.

Although a good deal of ingenuity was spent in weighing various definitions of foreign and US companies, the debate began to seem theological. Hecht, Cohen and Kline all agreed that what was needed was some sense from the Congress or the White House of a purposeful strategy to improve technology transfer, not a series of laws with complicated rules. But in the United States even to talk of 'industrial policy' is to hint at socialism and state control.

In any case, multinational corporations around the world are moving in their own directions, and not even the US government has much real power over their choices.
David Lindley

\section{South African ban}

SouTH Africa's Minister for Environmental Affairs, Gert Kotze, has announced that in line with the recent international decision banning all trade in ivory, the import and export of ivory through South Africa will be forbidden "at least through 1990". But Kotze also announced that South Africa will be joining the nine other African countries requesting reservations giving them permission to engage in controlled trading. South Africa has a regulated population of 8,200 elephants, and believes that a complete ban on ivory trading will undermine its successful management programme, although the country has allegedly been a poaching route for illegal ivory from other countries. M.C.

\section{Fusion director quits}

ROBERT $\mathrm{O}$. Hunter, controversial director of energy research at the US Department of Energy, resigned his position on 27 October after occupying it for a little more than a year. Hunter had become increasingly embroiled in a dispute over the future of the US fusion energy programme, and would have been called soon to testify again before the House Committee on Science, Space and Technology, where he recently endured a harangue from chairman Robert Roe (Democrat, New Jersey) and others.

D.L.

\section{British quartet named}

THE commercial-sector space mission Juno has announced the four final candidates from whom Britain's first astronaut will be chosen. They are Gordon Brooks, a 33-year-old physician in the Royal Navy; Major Timothy Mace of the Army Air Corps, also 33; Clive Smith, 27-year-old aerospace lecturer at Kingston Polytechnic; and Helen Sharman, aged 26, a food technologist. The four will train at the Glavcosmos facility near Moscow, and one will be chosen to join two Soviet cosmonauts in a flight in 1991. The $£ 16$ million needed to pay for the flight is to be raised by sponsorship; exactly what the sponsored astronaut will do in space has not yet been announced.

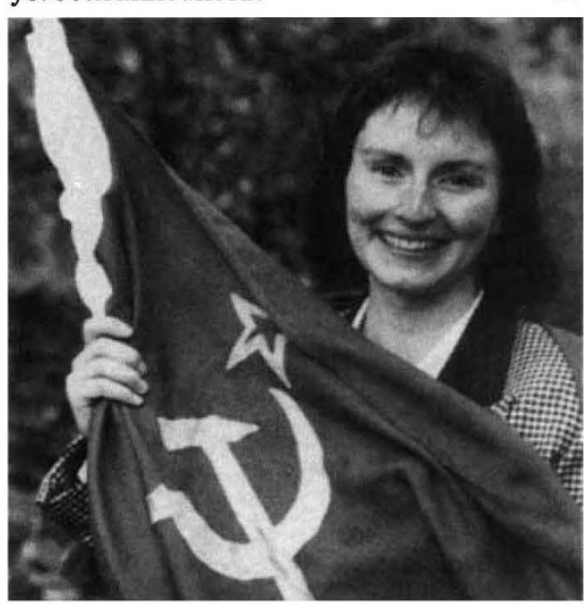

The space woman from Mars. Helen Sharman is a research technologist with Mars Confectionery. 